\title{
Unlocking pandemic potential: prevalence and spatial patterns of key substitutions in avian influenza H5N1 in Egyptian isolates
}

\author{
Sean G. Young ${ }^{1^{*}}$ (D), Andrew Kitchen ${ }^{2}$, Ghazi Kayali, ${ }^{3,4}$ and Margaret Carrele ${ }^{5,6}$
}

\begin{abstract}
Background: Avian influenza H5N1 has a high human case fatality rate, but is not yet well-adapted to human hosts. Amino acid substitutions currently circulating in avian populations may enhance viral fitness in, and thus viral adaptation to, human hosts. Substitutions which could increase the risk of a human pandemic (through changes to host specificity, virulence, replication ability, transmissibility, or drug susceptibility) are termed key substitutions (KS). Egypt represents the epicenter of human $\mathrm{H} 5 \mathrm{~N} 1$ infections, with more confirmed cases than any other country. To date, however, there have not been any spatial analyses of KS in Egypt.

Methods: Using 925 viral samples of H5N1 from Egypt, we aligned protein sequences and scanned for KS. We geocoded isolates using dasymetric mapping, then carried out geospatial hot spot analyses to identify spatial clusters of high KS detection rates. KS prevalence and spatial clusters were evaluated for all detected $\mathrm{KS}$, as well as when stratified by phenotypic consequence.
\end{abstract}

Results: A total of 39 distinct KS were detected in the wild, including 17 not previously reported in Egypt. KS were detected in 874 samples (94.5\%). Detection rates varied by viral protein with most KS observed in the surface hemagglutinin (HA) and neuraminidase (NA) proteins, as well as the interior non-structural 1 (NS1) protein. The most frequently detected KS were associated with increased viral binding to mammalian cells and virulence. Samples with high overall detection rates of KS exhibited statistically significant spatial clustering in two governorates in the northwestern Nile delta, Alexandria and Beheira.

Conclusions: KS provide a possible mechanism by which avian influenza H5N1 could evolve into a pandemic candidate. With numerous KS circulating in Egypt, and non-random spatial clustering of KS detection rates, these findings suggest the need for increased surveillance in these areas.

Keywords: Landscape genetics, Avian influenza, Egypt, Poultry

\section{Background}

Highly pathogenic avian influenza H5N1 has a case fatality rate approximately ten times higher than the H1N1 "Spanish Flu" pandemic of 1918, but has much lower infectivity $[1,2]$. Given the high pathogenicity of the virus, an H5N1 virus capable of airborne human-to-human transmission could lead to a devastating pandemic [3-5]. Indeed, this scenario has been predicted for many years $[1,2,6,7]$. A number of important genetic differences between avian

\footnotetext{
* Correspondence: SGYoung@uams.edu

${ }^{1}$ Department of Environmental and Occupational Health, University of

Arkansas for Medical Sciences, Little Rock, AR, USA

Full list of author information is available at the end of the article
}

and human strains of influenza exist, which have so far prevented $\mathrm{H} 5 \mathrm{~N} 1$ from being transmitted directly from human to human [8-11]. However, years of viral evolution in domestic poultry populations involving close contact with humans and other mammals has the potential to lead to an accumulation of mutations improving mammalian adaptation [1, 12].

Egypt has reported more confirmed human cases of avian $\mathrm{H} 5 \mathrm{~N} 1$ than any other country, and is regarded by many observers as the epicenter of human H5N1 infections [1, 13-17]. Human infections have been increasing in Egypt, and nearly all cases have been linked to direct contact with poultry [18]. The potential for direct

(C) The Author(s). 2018 Open Access This article is distributed under the terms of the Creative Commons Attribution 4.0 International License (http://creativecommons.org/licenses/by/4.0/), which permits unrestricted use, distribution, and 
human-poultry contact is high in Egypt. In addition to the commercial poultry industry, which supplies most of the meat consumed in the country, some 4-5 million Egyptian families raise poultry at home in backyard flocks $[19,20]$. A 3-year seroprevalence study found approximately $2 \%$ of Egyptians exposed to poultry had been infected with $\mathrm{H} 5 \mathrm{~N} 1$ [21]. Contact between human and avian hosts is a precondition for virus transfer, so an environment conducive to frequent contact, such as exists in Egypt, increases the probability of a human-adapted strain emerging [22, 23].

Genetic changes in viral proteins can have phenotypic consequences that increase pandemic risk [24]. A number of specific amino acid substitutions have been implicated in host specificity, particularly changes in the hemagglutinin (HA) protein that allow the virus to bind with and infect mammalian cells [2, 25-28]. In addition, there are genetic mutations known to alter the pathogenicity of the virus, increase the replicative ability of the polymerase complexes, and grant aerosol transmissibility without reassortment [28-31]. Viral genetic changes have been identified that alter susceptibility to current anti-viral drugs such as zanamivir and oseltamivir [24, 32]. All of the above are examples of phenotypic changes resulting from amino acid substitutions, often SNPs. Some potentially dangerous mutations may simultaneously compromise viral fitness, requiring the presence of other counteracting or "permissive" mutations to restore viral fitness in order to present a threat [33]. We refer to these genetic changes (or sets of concurrent changes) that alter host specificity, virulence, replication efficiency, transmissibility, or drug susceptibility in ways that increase human risk as key substitutions (KS).

Several KS have already been detected in Egypt, from samples at least as early as 2010 [18, 34, 35]. Gain-of-function studies have suggested that as few as four or five KS may be sufficient to provide H5N1 with airborne transmission, and at least two of these have been previously identified in Egyptian isolates [5, 31, 36]. Using viral genetic sequences for H5N1 uploaded to GenBank (https:// www.ncbi.nlm.nih.gov/genbank/), we performed a descriptive spatial analysis to examine the distribution of KS in Egypt [37]. A spatial analysis of KS in H5N1 influenza samples has not been performed previously, despite the importance of such information to a properly designed surveillance system and subsequent intervention efforts [13, 38]. Importantly, viruses can undergo local adaptation in response to environmental selective pressures and produce clusters of KS [39]. Areas where known KS occur with high frequency and exhibit non-random spatial clustering may indicate environments particularly conducive to the natural emergence of de novo KS.

\section{Methods}

We obtained Egyptian H5N1 sequences collected between 2005 and 2015 from the Influenza Virus Sequence
Database, hosted by the National Center for Biotechnology Information (NCBI) [40]. We extracted metadata for Egyptian samples, including geographic location information, from the full GenBank records, obtained using the Entrez Direct utilities via UNIX terminal [37, 41]. Inclusion criteria included all partial and complete protein sequences from avian hosts (both poultry and wild birds) with a geographic location more detailed than "Egypt." A large number of H5N1 KS have been identified by the WHO Collaborating Center for Influenza Reference and Research at the CDC and are catalogued in a Genetic Changes Inventory, publicly available online (www.cdc.gov/flu/avianflu/h5n1/inventory.htm). We used this inventory in the current study as the definitive list of known KS. KS have been identified in all 10 viral proteins, including the surface proteins HA and neuraminidase (NA) responsible primarily for virus binding, cell fusion, and viral release, and the internal proteins (M1, M2, NP, NS1, NS2, PB1, PB1-F2, and PB2) involved in viral structure, replication, suppressing host antiviral response, and more [2]. We performed an initial screening for over $100 \mathrm{KS}$, ultimately testing for the presence of 39 separate substitutions.

Most of the selected KS $(n=29)$ are SNPs, such as the substitution from glutamic acid to lysine at position 627 (E627K) in the PB2 gene, shown to enhance mammalian host adaptation; two KS are amino acid deletions; and the remaining eight $\mathrm{KS}$ are sets of mutations (i.e., KS formed from the interaction of multiple independent substitutions), such as the dual substitutions of N200S in the NS1 gene and T47A in the NS2 gene, which together decrease host antiviral response but do not constitute KS individually. Table 1, adapted from the CDC's Genetic Changes Inventory, lists all detected KS in Egypt, including the number of isolates in which each KS was detected, whether or not the KS had been previously reported in Egypt, and the phenotypic consequences identified in previous literature. All $39 \mathrm{KS}$ are associated with increased human risk, with two partial exceptions: 1) a triple substitution of S155 N, T156A, and S223 N in the HA gene associated with both increased mammalian adaptation and reduced lethality in mice; and 2) the N66S substitution in the PB1-F2 gene associated with increased virulence and increased host antivirus response [42-45]. We selected five phenotypic consequences groups (PCGs) using the CDC's Inventory to group KS by the resultant changes in viral characteristics (i.e. phenotypic consequences): PCG1 - host specificity, PCG2 - virulence, PCG3 - replication efficiency, PCG4 - transmissibility, and PCG5 - antiviral susceptibility. These phenotypic consequences were identified by the CDC as "signal[ing] adaptation to mammalian species or alter[ing] susceptibility to existing antivirals" thereby rendering the virus more dangerous to humans [46]. 
Table 1 Detected KS in Egypt with phenotypic consequences and references, adapted from CDC's Inventory

\begin{tabular}{|c|c|c|c|c|}
\hline Protein & Amino Acid Change(s) & Detections in Egypt & Previously Reported in Egypt & Phenotypic Consequences \\
\hline \multirow[t]{21}{*}{ HA } & D94N & 738 & Yes & $\begin{array}{l}\text { Increased viral binding to alpha,2-6; enhanced virus } \\
\text { fusion [59] }\end{array}$ \\
\hline & $\mathrm{S} 133 \mathrm{~A}$ & 40 & Yes & Increased pseudovirus binding to alpha,2-6 [77] \\
\hline & A134V & 1 & Yes & Increased infectivity in SIAT Cells $[78,79]$ \\
\hline & G139R & 7 & No & Increased virus binding to alpha,2-6 [80] \\
\hline & S155N & 470 & Yes & Increased virus binding to alpha,2-6 [81] \\
\hline & $\mathrm{T} 156 \mathrm{~A}$ & 656 & Yes & $\begin{array}{l}\text { Increased virus binding to alpha,2-6 and increased } \\
\text { transmission in guinea pigs }[81,82]\end{array}$ \\
\hline & N182K & 3 & Yes & Increased virus binding to alpha,2-6 $[78,80,83]$ \\
\hline & E186G & 1 & No & Increased virus binding to alpha,2-6 [25] \\
\hline & T1881 & 17 & Yes & Increased pseudovirus binding to alpha,2-6 [77] \\
\hline & K189R & 722 & Yes & Increased virus binding to alpha,2-6 [81] \\
\hline & Q192R/H & 11 & Yes & Increased virus binding to alpha,2-6 $[25,80,84]$ \\
\hline & N193K & 1 & No & Increased virus binding to alpha,2-6 [80] \\
\hline & V210l & 12 & Yes & Increased virus binding to alpha,2-6 [84] \\
\hline & S223N & 6 & Yes & Increased virus binding to alpha, $2-6[25,78,83,85,86]$ \\
\hline & P235S & 733 & Yes & Increased virus binding to alpha,2-6 [84] \\
\hline & E75K, S123P & 1 & No & Increased virus binding to alpha,2-6 [80] \\
\hline & L129-, I151T & 453 & Yes & Increased virus binding to alpha,2-6 $[84,87]$ \\
\hline & S133A, T188I & 1 & No & Increased pseudovirus binding to alpha,2-6 [77] \\
\hline & S155N, T156A & 359 & Yes & Increased virus binding to alpha,2-6 [81] \\
\hline & S155N, T156A, S223N & 3 & No & $\begin{array}{l}\text { Increased virus binding to alpha,2-6; reduced lethality and } \\
\text { systemic spread in mice [42] }\end{array}$ \\
\hline & T156A, S223N & 6 & No & Increased virus binding to alpha,2-6 [81] \\
\hline \multirow[t]{2}{*}{ M1 } & N30D & 99 & Yes & Increased virulence in mice [88] \\
\hline & $\mathrm{T} 215 \mathrm{~A}$ & 100 & No & Increased virulence in mice [88] \\
\hline \multirow[t]{2}{*}{ M2 } & V27A & 1 & No & $\begin{array}{l}\text { Reduced susceptibility to amantadine and rimantadine } \\
\text { [89-92] }\end{array}$ \\
\hline & S31N/G & 53 & Yes & $\begin{array}{l}\text { Reduced susceptibility to amantadine and rimantadine } \\
{[89,90,93-97]}\end{array}$ \\
\hline \multirow[t]{5}{*}{ NA } & 49-68 deletion & 366 & Yes & Enhanced virulence in mice $[98,99]$ \\
\hline & $197 \mathrm{~V}$ & 1 & No & Reduced susceptibility to oseltamivir [100-102] \\
\hline & $1203 \mathrm{M} / \mathrm{L} / \mathrm{L} / \mathrm{K} / \mathrm{R}$ & 1 & No & Reduced susceptibility to oseltamivir [103-107] \\
\hline & $\mathrm{H} 254 \mathrm{Y} / \mathrm{R}$ & 379 & No & $\begin{array}{l}\text { Reduced susceptibility to oseltamivir and peramivir } \\
{[103,108-112]}\end{array}$ \\
\hline & N275S & 4 & Yes & $\begin{array}{l}\text { Reduced susceptibility to oseltamivir } \\
{[106,108,109,113-115]}\end{array}$ \\
\hline \multirow[t]{4}{*}{ NS1 } & P42S & 118 & Yes & Increased virulence in mice [116] \\
\hline & 80-84 deletion & 128 & Yes & Increased virulence in mice $[117,118]$ \\
\hline & L98F & 111 & No & Increased virulence in mice $[119,120]$ \\
\hline & $1101 \mathrm{M}$ & 118 & No & Increased virulence in mice $[119,120]$ \\
\hline NS1 \& NS2 & $\begin{array}{l}\text { N200S (NS1), T47A } \\
\text { (NS2) }\end{array}$ & 38 & No & Decreased antiviral response in host [121] \\
\hline PB1-F2 & N66S & 1 & Yes & $\begin{array}{l}\text { Increased virulence, replication efficiency, and antivirus } \\
\text { response in mice [43-45] }\end{array}$ \\
\hline PB2 & E627K & 94 & Yes & $\begin{array}{l}\text { Increased replication efficiency in cell culture and enhanced } \\
\text { virulence in mice; enhanced polymerase activity and }\end{array}$ \\
\hline
\end{tabular}


Table 1 Detected KS in Egypt with phenotypic consequences and references, adapted from CDC's Inventory (Continued)

\begin{tabular}{|c|c|c|c|c|}
\hline Protein & Amino Acid Change(s) & Detections in Egypt & Previously Reported in Egypt & Phenotypic Consequences \\
\hline & & & & $\begin{array}{l}\text { mammalian host adaptation; transmissible among ferrets } \\
{[29,31,122-131]}\end{array}$ \\
\hline & D701N & 1 & No & $\begin{array}{l}\text { Enhanced replication efficiency, increased virulence and } \\
\text { transmission in guinea pigs; mammalian host adaptation; } \\
\text { increased virulence in mice }[27,82,127,132]\end{array}$ \\
\hline & $\begin{array}{l}\text { L89V, G309D, } \\
\text { T339L, R477G, } \\
\text { I495V, L627E, } \\
\text { A676T }\end{array}$ & 1 & No & $\begin{array}{l}\text { Enhanced polymerase activity and increased virulence in } \\
\text { mice [60] }\end{array}$ \\
\hline
\end{tabular}

We aligned the sequences with the A/Vietnam/1203/ 2004 virus, except for the NA and NS1 proteins, which we aligned with A/goose/Guangdong/1/1996, for consistent amino acid numbering with the CDC's Inventory, and then tested for the presence of each selected KS. H5N1 samples in GenBank varied in the number of proteins for which full sequence data were available. This variation occurs when researchers choose not to sequence certain proteins or fail to upload sequences to GenBank due to quality concerns, such as unconfirmed frame shifts. As not all proteins were present in GenBank for each virus sample, the specific number of KS tested for varied between samples. Detection rates by viral sample were calculated as the number of $\mathrm{KS}$ detected divided by the number of KS tested for, which varied according to the number of proteins sequenced for each isolate. Results were summarized by viral protein, sample year, and by PCG.

Geospatial hot spot analyses have been used to help target areas with a disproportionate burden of disease [47, 48]. We employed the Getis-Ord Gi* statistic to identify statistically significant hot spots, or spatial clusters of elevated rates of KS detection [49]. The Getis-Ord $\mathrm{Gi}^{*}$ has been shown to be effective even with low incidence rates [49, 50]. For a hot spot to be detected, a location with a high

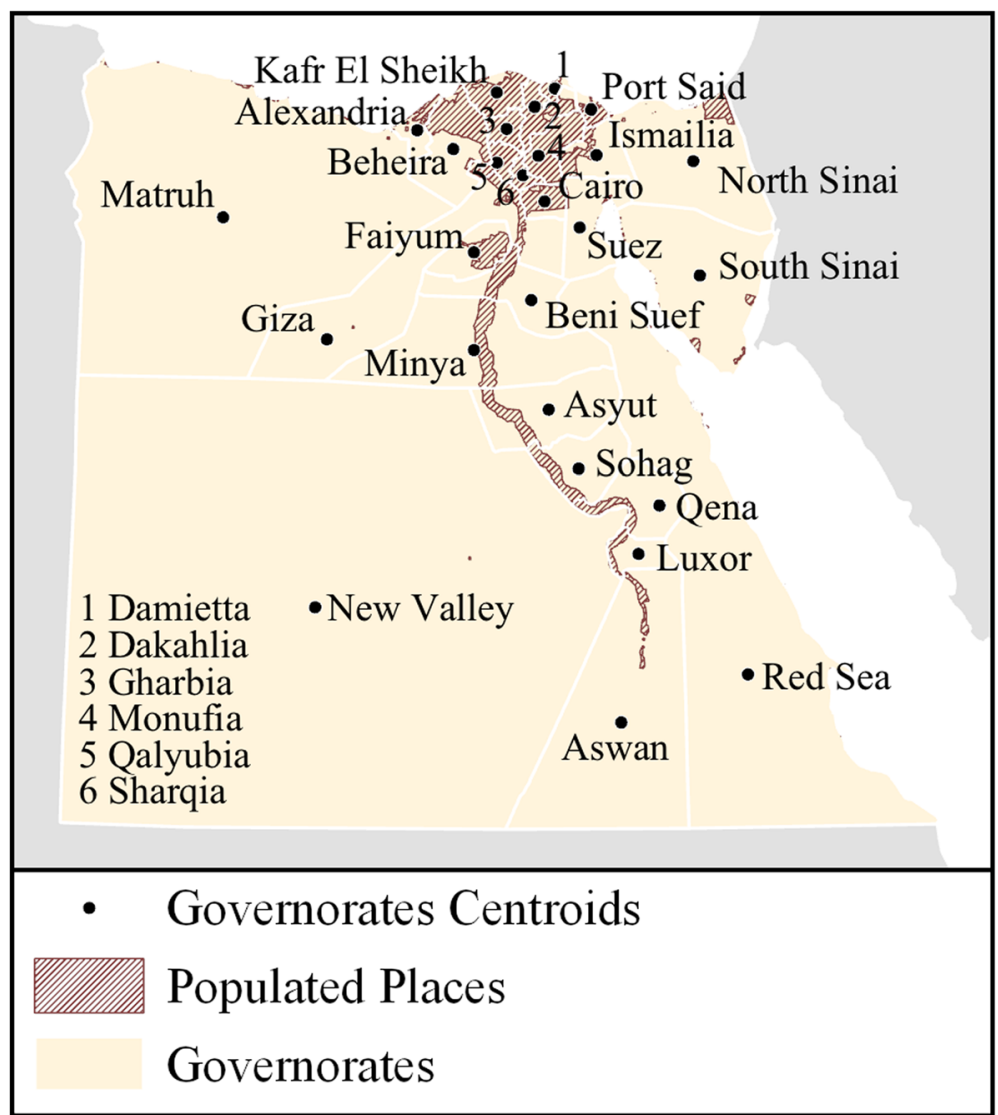

Fig. 1 Locations for which spatial clusters of high KS detection rates were evaluated. Governorate centroids and boundaries shown, with dasymetrically-adjusted populated places shown with hatching 
value (e.g., many KS detected) must have neighbors with high values. Neighbors are determined in one of two ways. First, because the scale at which clustering occurs is not known a priori, we used Incremental Spatial Autocorrelation to identify a statistically significant peak distance at which clustering across the whole study area was most pronounced [51-53]. This distance was then used to select neighbors during hot spot analyses. If no peak was detected, an average distance was calculated to yield thirty neighbors. The local sum for a feature and its neighbors is compared proportionally to the sum of all features, then a $\mathrm{z}$-score is calculated to determine when this difference is too large to be the result of random chance. Statistical significance is adjusted to account for multiple testing and spatial dependence using Benjamini's and Hochberg's false detection rate (FDR) correction, which reduces the critical $p$-value thresholds as a function of the number of input features and the neighborhood structure used $[54,55]$.

The majority of H5N1 samples from Egypt did not include geographic information below the governorate level to allow hot spot detection, consequently dasymetric adjustment was employed to approximate sample locations within governorates [56]. We randomly distributed point locations only within populated places, as identified using the 2010 population density estimates from worldpop.org with a minimum density value of 10 persons per square kilometer [57]. This removed large uninhabited portions of many governorates from the analysis. Acknowledging the bias introduced by estimating point locations, the random distribution of points was repeated 10,000 times, with hot spot analysis performed after each iteration. Only statistically significant hot spots $(p \leq 0.05)$ were kept. We summarized results for each governorate by counting the total number of iterations in which at least one hot spot was detected. We considered governorates with 9500 or more detections to be probable hot spots. For comparison, we also performed a single hot spot analysis using each governorate's geometric centroid, consistent with prior phylogeographic studies of influenza in Egypt [16, 58]. Figure 1 shows the sets of locations for which spatial clusters of high KS detection rates were evaluated.

\section{Results}

From 2006 to 2015, 925 H5N1 samples with at least one sequenced gene segment and a geographic location more detailed than "Egypt" were listed in GenBank. Of these, 874 samples contained at least one KS (94.5\%), with an average of 3 PCGs represented. The majority of KS-positive samples (584/925) were located in Lower Egypt, particularly in the governorates of Alexandria $(n=50)$, Beheira $(n=96)$, Monufia $(n=90)$, Qalyubia $(n=109)$, Dakahlia $(n=82)$, and Sharqia $(n=88)$ (see Fig. 2$)$.

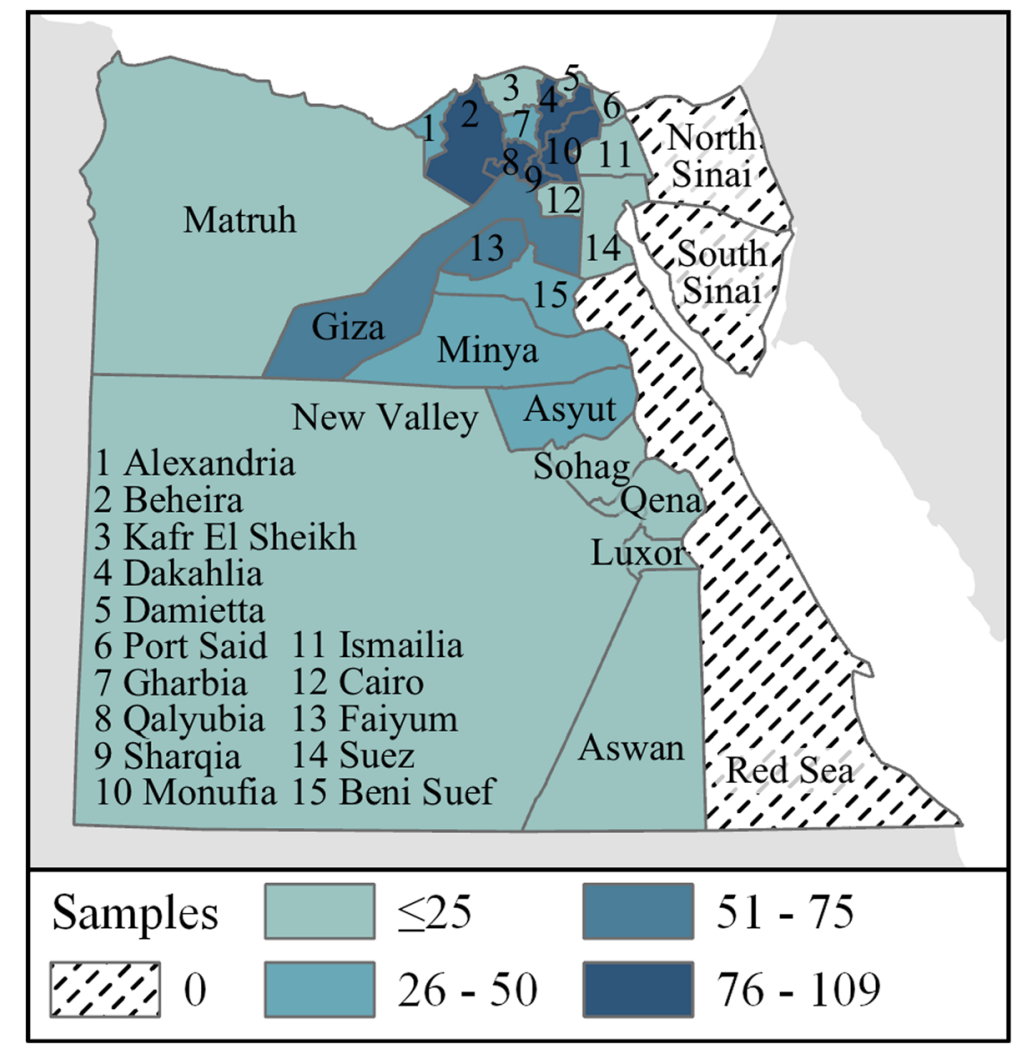

Fig. 2 Counts of viral samples that met inclusion criteria by governorate 
Table 2 Summary of KS detections by viral protein

\begin{tabular}{lll}
\hline Protein & \# of KS & \# of Samples with KS Detected/Total Samples (\%) \\
\hline HA & 21 & $789 / 825(95.6)$ \\
M1 & 2 & $100 / 112(89.3)$ \\
M2 & 2 & $54 / 103(52.4)$ \\
NA & 5 & $381 / 381(100)$ \\
NS1 & 4 & $130 / 130(100)$ \\
NS2 & 1 & $38 / 108(35.2)$ \\
PB1-F2 & 1 & $1 / 88(1.1)$ \\
PB2 & 3 & $94 / 116(81)$ \\
Total $^{a}$ & 39 & $874 / 925(94.5)$ \\
\hline
\end{tabular}

${ }^{a}$ Many samples included multiple protein sequences, so the total number of samples is smaller than the sum of the individual protein sequences would suggest

The most commonly sequenced protein was HA $(n=825)$, followed by NA $(n=381)$; other viral proteins were much less frequent in the GenBank data. Detection rates varied by protein with the NA and NS1 proteins having one or more KS present in $100 \%$ of samples tested, while the PB1-F2 protein had only a single detected KS out of 88 samples tested. The average number of KS tested for was 22.6 per sample, with an average of 6.4 KS detected, giving an overall mean detection rate of 0.28 . A total of $39 \mathrm{KS}$ were detected at least once in H5N1 samples from Egypt. Table 2 summarizes the detected KS by protein and includes the proportion of samples in which KS were present.

Although H5N1 was first reported in Egypt in 2006, 2 positive viral samples were collected in December 2005. The number of isolates uploaded to GenBank with governorate location information rose above 100 each year in 2007-2010, but dropped after 2011. Similarly, the average number of proteins sequenced per virus ranged from a high of 2.7 in 2008 to a low of 1.3 in 2014 . Between 2005 and 2015, mean detection rates by year (total KS detected per year divided by total KS tested for in that year) ranged from a high of 0.38 in 2007 to a low of 0.18 in 2014. Figure 3 summarizes the temporal distribution of detected KS by year, with the 95\% margin of error for $\mathrm{KS}$ detection rates shown.

The single most commonly detected KS was the change in the HA protein at amino acid site 94 from aspartic acid to asparagine, associated with increased virus binding to human sialic acid receptors [59]. KS were grouped according to phenotypic consequences as identified in the CDC's Inventory. Among the detected KS were several not previously reported in Egypt $(n=17)$, representing all 5 PCGs and including 5 of the 8 detected KS associated with antiviral susceptibility. One $\mathrm{KS}$ not previously reported in Egypt was a set of 7 amino acid substitutions in the PB2 gene, associated with both PCG 2 and PCG 3 [60]. For a full list of detected KS with phenotypic consequences, see Table 1. The number of viral samples with one or more detected KS in each group as well as mean detection rates by PCG are summarized in Table 3.

\section{Results of hot spot analyses}

Two governorates contained probable hot spots of overall KS detection rates using both governorate centroids (single run) and dasymetrically-adjusted governorate boundaries (>9500 iterations): Alexandria and Beheira. These two governorates are immediate neighbors in the northwestern portion of the Nile River Delta (see Fig. 4). No other governorates were identified as hot spots using centroids, and no other governorates exceeded the threshold of 9500 iterations using dasymetric adjustment.

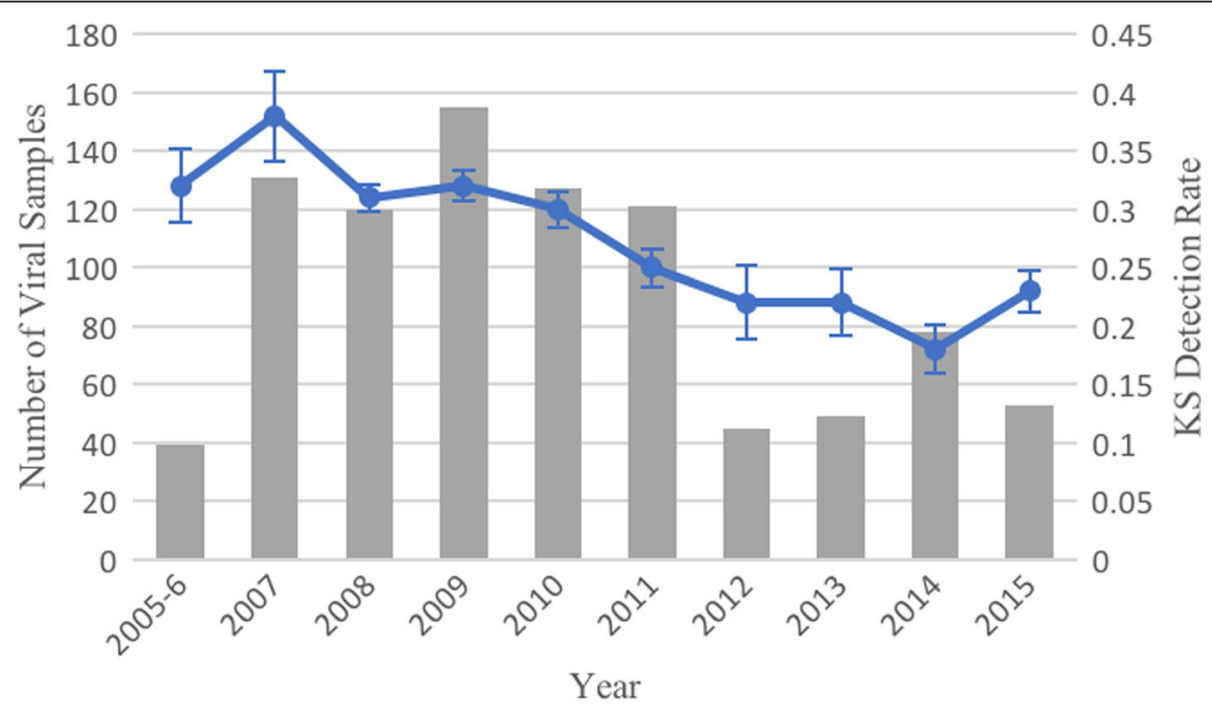

Fig. 3 Temporal distribution of viral samples and KS detection rates by year 
Table 3 Summary of detected KS by phenotypic consequences groups (PCG)

\begin{tabular}{llll}
\hline Phenotypic Consequences Group (PCG) & KS in PCG & Samples w/ KS Detected & Mean Detection Rate \\
\hline PCG1: Host Specificity & 23 & $800 / 836$ & 0.26 \\
PCG2: Virulence & 13 & $851 / 918$ & 0.58 \\
PCG3: Replication & 5 & $98 / 846$ & 0.08 \\
PCG4: Transmissibility & 3 & $704 / 836$ & 0.71 \\
PCG5: Antiviral Susceptibility & 8 & $400 / 446$ & 0.25 \\
\hline
\end{tabular}

Geospatial hot spots were also evaluated for individual PCGs, using a $p$-value cutoff of 0.05 to evaluate statistical significance. We detected probable hot spots based upon dasymetric adjustment for PCG1 in Alexandria and Beheira and for PCG2 only in Beheira, however the remaining PCGs falling below the 9500 iterations threshold. Results were not consistent between centroid and dasymetrically-adjusted analyses. Using a single iteration with all samples placed at governorate centroids, hot spots were found for PCG1 in Beni Suef, Dakahlia, and Faiyum; for PCG2 in Alexandria and Beheira; and for PCG4 in Asyut, Faiyum, and Monufia; while PCG3 and PCG5 again did not contain any hot spots (see Fig. 5). The number of iterations in which probable hot spots were detected using dasymetric adjustment, as well as detections using centroids, are shown in Table 4.

\section{Discussion}

This work represents the first spatial analysis of KS in $\mathrm{H} 5 \mathrm{~N} 1$ avian influenza virus in Egypt, and the first use of geospatial hot spot analysis for influenza KS. The majority of viral samples $(874 / 925)$ contained one or more KS, with 39 distinct KS detected including from each of the five PCGs. The circulation of so many KS increases the probability of recombination and reassortment producing viral genomes with combinations of KS that prove to be well-adapted to infect, replicate in, and transmit between humans.

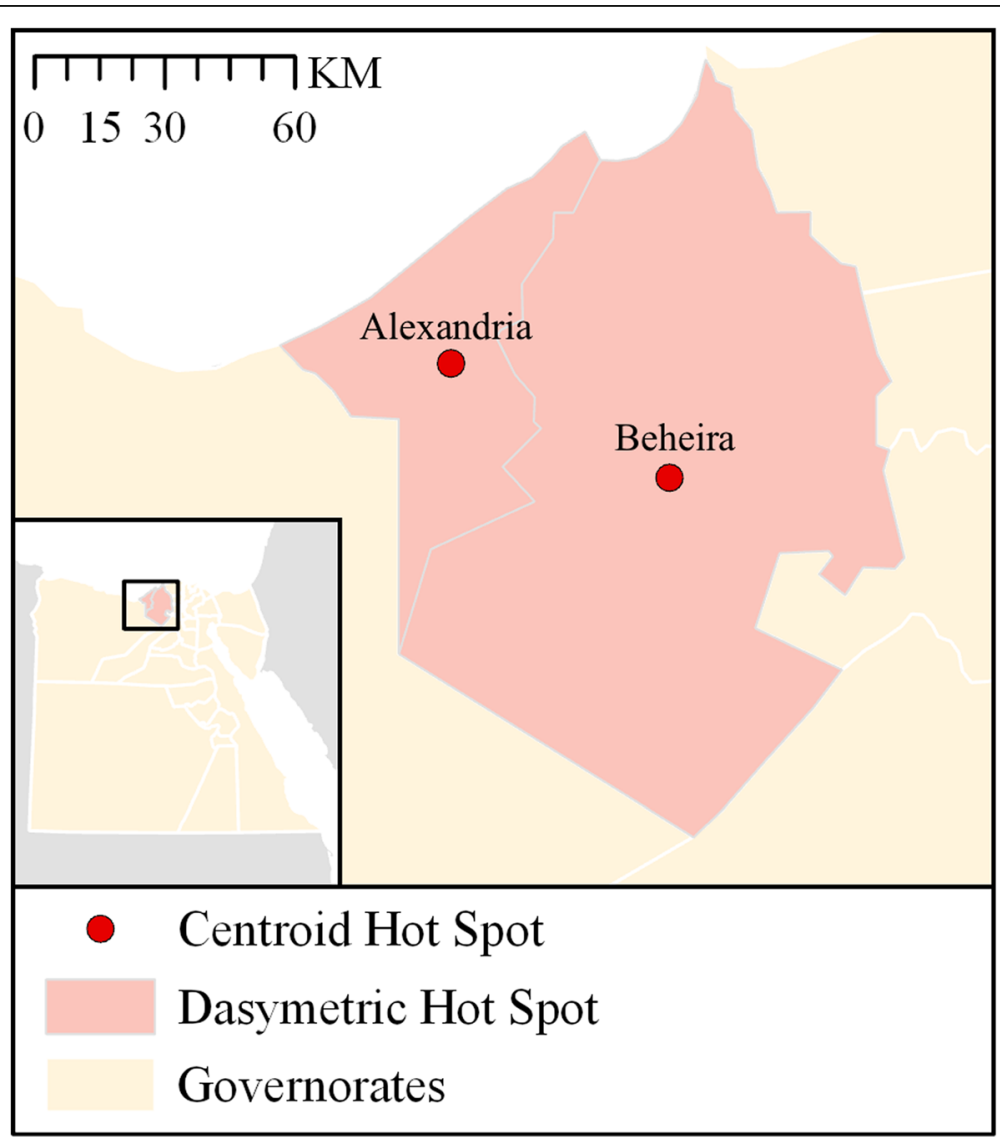

Fig. 4 Summary of hot spot analyses for overall KS detection rates. The governorates of Alexandria and Beheira were the only locations identified as containing probable hot spots using both dasymetric adjustment (> 9500 iterations) and governorate centroids 


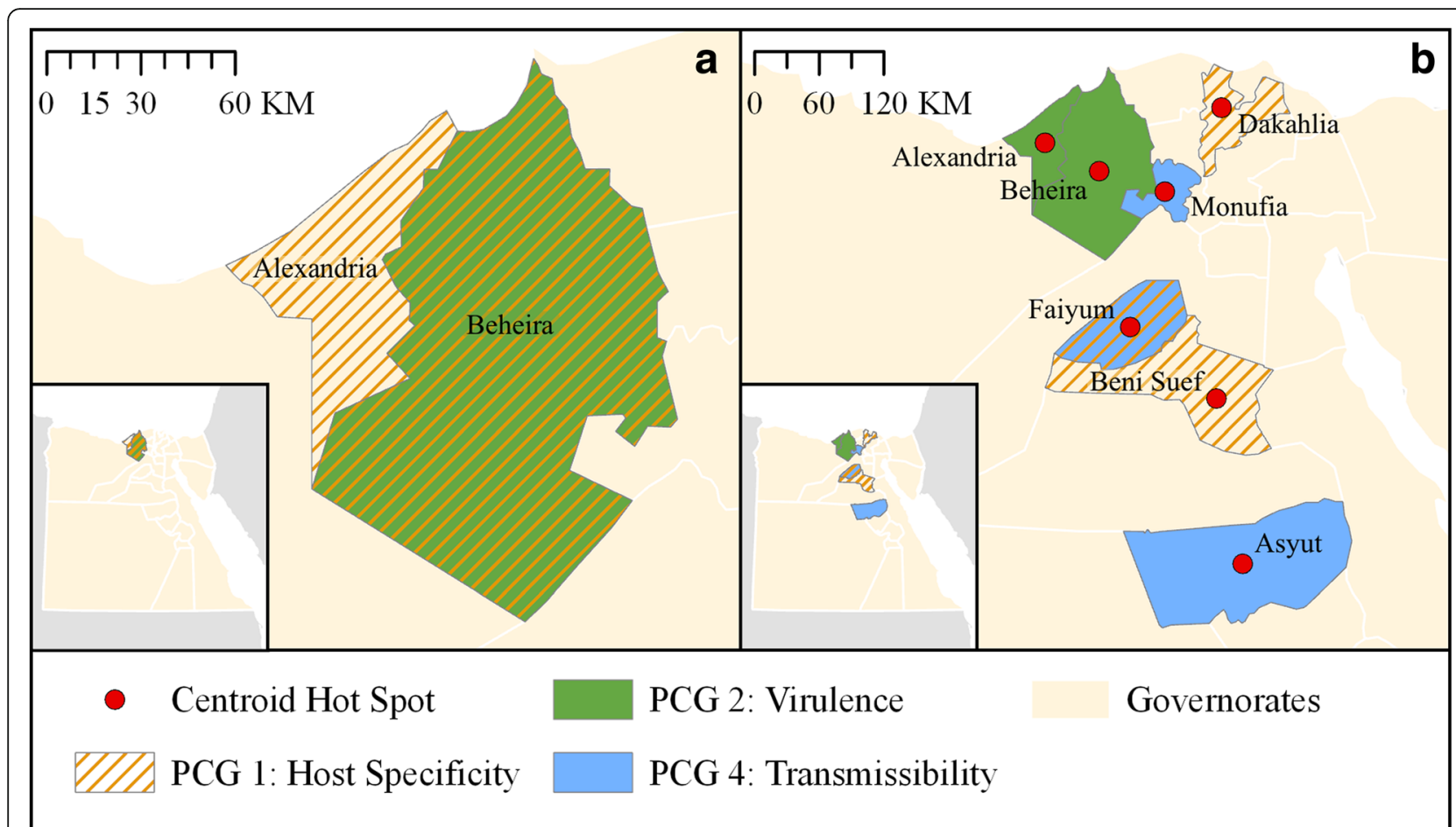

Fig. 5 Summary of hot spot analyses for KS detection rates by PCG, using (a) dasymetrically-adjusted sample locations (>9500 iterations), and (b) governorate centroids

Samples with governorate location information uploaded to GenBank varied from year to year, with a low of 39 in 2005-6 and a high in 2009 with 155 isolates, however the sample sizes dropped after 2011. It is not entirely clear why fewer isolates from Egypt are being uploaded to GenBank than previously, although political turmoil and social unrest in the wake of the 2011 revolution are likely responsible. Detection rates of $\mathrm{KS}$ also varied, trending down during the study period from a high of 0.38 in 2007 to a low of 0.18 in 2014 (see Fig. 3). This decline is likely driven a smaller number of protein sequences per sample being uploaded in later years of the study period, with the HA gene being the most commonly uploaded. HA sequences tend to have lower detection rates due to the larger number of known HA KS being tested for. The problem of outdated or incomplete reporting of avian influenza is not new in the country, and several studies suggest the true burden of disease in Egypt is severely underestimated $[3,61]$. Given the inefficiency in past years of vaccination efforts in the country, there is a pressing need for increased biosecurity and public health education to help limit direct contact between humans and poultry [62-64]. Due to limited resources, the ability to focus such campaigns in regions of greatest need is one of the primary contributions of this work.

Spatial clusters of overall KS detection rates were identified using hot spot analyses in the northwestern portion of the Nile River delta region in Egypt, specifically within the governorates of Alexandria and Beheira. Hot spots were also identified for individual PCGs, however the reduced sample sizes resulting from splitting the dataset into PCGs increased the variability. This can be observed in the differences between the results using dasymetrically-adjusted locations and those using centroids. For example, hot spots were detected using centroids in Beni Suef, Dakahlia, and Monufia governorates for various PCGs, despite these governorates containing hot spots in less than half of the iterations using the dasymetrically-adjusted locations. Since both centroids and dasymetrically-adjusted locations are estimates, the latter method is preferable as its iterative nature (i.e., 10,000 replicate analyses) provides an indication of the reliability of our estimates and does not assume all samples were collected at the geometric centroid of the governorate. Using dasymetrically-adjusted locations, spatial clusters of KS detection rates were identified only in Alexandria and Beheira for KS related to host specificity and virulence (PCG1 and 2).

The city of Alexandria is the second largest city in Egypt and an important seaport, as well as a popular tourist destination. The neighboring governorate of Beheira is located between Alexandria and Cairo, experiencing substantial transport between those two urban centers. A study in Beheira in 2015 claimed the majority of the population was involved in raising poultry, and found most poultry growers demonstrated poor practices with regards to avian 
Table 4 Results of hot spots analyses for overall KS detection rates and by PCG

\begin{tabular}{|c|c|c|c|c|c|c|}
\hline Governorate & Overall KS & PCG1 & PCG2 & PCG3 & PCG4 & PCG5 \\
\hline Alexandria & $10000^{a}$ & 9927 & $9187^{a}$ & 17 & 35 & 2055 \\
\hline Aswan & 0 & 115 & 0 & 0 & 132 & 0 \\
\hline Asyut & 0 & 1 & 0 & 0 & $7891^{a}$ & 0 \\
\hline Beheira & $10000^{\mathrm{a}}$ & 9909 & $9778^{a}$ & 1483 & 2025 & 5304 \\
\hline Beni Suef & 0 & $4533^{a}$ & 1 & 3 & 2918 & 0 \\
\hline Cairo & 4 & 0 & 10 & 0 & 1 & 0 \\
\hline Dakahlia & 2 & $677^{\mathrm{a}}$ & 103 & 51 & 658 & 9 \\
\hline Damietta & 0 & 9 & 1 & 26 & 24 & 0 \\
\hline Faiyum & 2 & $5405^{a}$ & 0 & 632 & $8490^{\mathrm{a}}$ & 3 \\
\hline Gharbia & 6955 & 4843 & 3649 & 422 & 1971 & 3092 \\
\hline Giza & 143 & 217 & 133 & 52 & 477 & 0 \\
\hline Ismailia & 0 & 0 & 0 & 0 & 1 & 1 \\
\hline Kafr El Sheikh & 6649 & 5308 & 3333 & 920 & 1700 & 2143 \\
\hline Luxor & 0 & 83 & 0 & 0 & 471 & 0 \\
\hline Matruh & 326 & 184 & 62 & 0 & 0 & 49 \\
\hline Minya & 0 & 124 & 0 & 0 & 1214 & 0 \\
\hline Monufia & 2460 & 942 & 1484 & 557 & $1738^{\mathrm{a}}$ & 310 \\
\hline New Valley & 0 & 6 & 0 & 0 & 200 & 0 \\
\hline North Sinai & - & - & - & - & - & - \\
\hline Port Said & 0 & 0 & 0 & 22 & 0 & 5 \\
\hline Qalyubia & 0 & 0 & 2 & 0 & 0 & 0 \\
\hline Qena & 0 & 111 & 0 & 0 & 357 & 0 \\
\hline Red Sea & - & - & - & - & - & - \\
\hline Sharqia & 0 & 0 & 0 & 16 & 7 & 0 \\
\hline Sohag & 0 & 1467 & 0 & 0 & 1692 & 0 \\
\hline South Sinai & - & - & - & - & - & - \\
\hline Suez & 0 & 1 & 0 & 0 & 3 & 0 \\
\hline
\end{tabular}

The number of iterations (out of 10,000) in which statistically significant hot spots were detected using dasymetric adjustment is shown for each

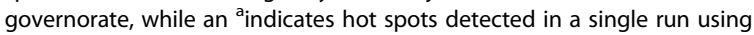
governorate centroids

influenza prevention and control [65]. Spatial clustering of high rates of KS in this area suggests increased surveillance is warranted. It is not clear if the detected KS represent de novo mutations in Egypt, or are being introduced from outside the country. The identification of Alexandria and Beheira as a cluster of KS detections may suggest the latter due to their location on the Black Sea/Mediterranean flyway, but more work is required to determine this with confidence [66-69]. If the majority of detected KS are the result of viral introductions, it might partially explain the observed spatial patterns, including the relatively low rates in and around Cairo.

A limitation of this analysis was that in most governorates sample sizes were too small to allow for time series analyses of detected hot spots, therefore spatial clusters were assumed to be consistent over the 10-year study period. We were also limited by the lack of fine-grain geographic location information for influenza sequences on GenBank, which were the primary source of data for this study. Recognized by previous researchers as an important shortcoming to the otherwise incredibly useful datasets available through GenBank, the lack of consistency and infrequent inclusion of sub-governorate location information required the use of approximation methods which introduced uncertainty into the analyses [70-72]. Previous spatial investigations of Egyptian isolates relied solely on geographic centroids of governorates, or even the country $[16,58,73-75]$. This and many other studies focused on the spatial dynamics of genetic data would benefit immensely from improved geographic resolution in GenBank records. We call on researchers uploading genetic data to GenBank and similar repositories to include as much geographic detail in the metadata as possible, while respecting privacy considerations when appropriate. Sampling bias, both in terms of geographic locations chosen for sample collection and in terms of genes selected for sequencing, was a challenge for this study as with all secondary analyses. It is difficult to know to what extent such bias introduced uncertainty into the current analysis. While sampling would appear to be concentrated in the most densely populated areas of the country (see Figs. 1 and 2), it is unclear from the information available in GenBank what sampling strategies were employed or why full genome sequences were not collected or cataloged. Another challenge was that at the time of this writing, the CDC's H5N1 Genetic Changes Inventory had not been updated since June 26, 2012. This corresponds with the publication of two papers detailing gain-of-function experiments in which KS allowing avian H5N1 transmission between mammals were identified and described, leading to concerns about public dissemination of KS information [31, 36, 76]. Despite the recent lifting of the NIH's funding pause on gain-of-function studies in December 2017, no updates to the June 2012 edition of the inventory were published prior to this study.

\section{Conclusions}

This work provides a descriptive baseline for the distribution and spatial clustering of KS in Egypt, from which future studies can be compared. High overall detection rates of KS were found to cluster spatially in the northwestern portion of the Nile River delta. Large numbers of KS were detected with a range of associated phenotypic consequences, which raise concerns of a pandemic strain developing in the region. Better geographic data and improved genetic surveillance are necessary to properly evaluate and monitor this potential threat to global public health. 


\section{Abbreviations}

HA: Hemagglutinin; KS: Key substitutions; MP: Matrix protein; NA: Neuraminidase; NP: Nucleoprotein; NS: Non-structural protein; PA: RNA polymerase subunit; PB1: RNA polymerase subunit; PB2: RNA polymerase subunit; PCG: Phenotypic Consequence Group

\section{Funding}

This work was supported by NSF Grant \#0966130 and DMID contract HHSN272201400006C. The funding sources had no involvement in study design, analyses, writing, or decision to publish.

\section{Availability of data and materials}

The genetic sequence and location data used are publicly available from the Influenza Virus Sequence Database, hosted by the National Center for Biotechnology Information: https://www.ncbi.nlm.nih.gov.

\section{Authors' contributions}

SGY and MC developed the study concept and design; SGY, AK, and MC performed the analyses and interpreted the data; SGY created the figures; SGY, AK, GK, and MC wrote the manuscript. All authors read and approved the final manuscript draft.

\section{Ethics approval and consent to participate}

Not applicable.

\section{Consent for publication}

Not applicable.

\section{Competing interests}

The authors declare that they have no competing interests.

\section{Publisher's Note}

Springer Nature remains neutral with regard to jurisdictional claims in published maps and institutional affiliations.

\section{Author details}

${ }^{1}$ Department of Environmental and Occupational Health, University of Arkansas for Medical Sciences, Little Rock, AR, USA. ${ }^{2}$ Department of Anthropology, University of lowa, lowa City, IA, USA. ${ }^{3}$ Department of Epidemiology, Human Genetics, and Environmental Sciences, University of Texas Health Sciences Center, Houston, TX, USA. ${ }^{4}$ Department of Scientific Research, Human Link, Hazmieh, Lebanon. ${ }^{5}$ Department of Geographical and Sustainability Sciences, University of lowa, lowa City, IA, USA. ${ }^{6}$ Department of Epidemiology, University of lowa, lowa City, IA, USA.

Received: 18 May 2017 Accepted: 28 June 2018

Published online: 06 July 2018

\section{References}

1. Perovic VR, Muller CP, Niman HL, Veljkovic N, Dietrich U, Tosic DD, et al. Novel phylogenetic algorithm to monitor human tropism in Egyptian H5N1-HPAIV reveals evolution toward efficient human-to-human transmission. PLoS One. 2013:8:e61572.

2. Gambotto A, Barratt-Boyes SM, de Jong MD, Neumann G, Kawaoka Y. Human infection with highly pathogenic H5N1 influenza virus. Lancet. 2008; 371:1464-75.

3. Kayali G, Kandeil A, El-Shesheny R, Kayed AS, Maatouq AM, Cai Z, et al. Avian influenza a(H5N1) virus in Egypt. Emerg Infect Dis. 2016;22:379-88.

4. Kim J-K, Kayali G, Walker D, Forrest HL, Ellebedy AH, Griffin YS, et al. Puzzling inefficiency of H5N1 influenza vaccines in Egyptian poultry. Proc Natl Acad Sci. 2010:107:11044-9.

5. Neumann G, Macken CA, Karasin Al, Fouchier RAM, Kawaoka Y. Egyptian H5N1 influenza viruses_cause for concern? PLoS Pathog. 2012;8:e1002932.

6. Webster RG, Walker EJ. Influenza: the world is teetering on the edge of pandemic that could kill a large fraction of the human population. Am Sci. 2003:91:122-9.

7. Kayali G, El-Shesheny R, Kutkat MA, Kandeil AM, Mostafa A, Ducatez MF, et al. Continuing threat of influenza (H5N1) virus circulation in Egypt. Emerg Infect Dis. 2011;17:2306-8.

8. Neumann G, Kawaoka Y. Host range restriction and pathogenicity in the context of influenza pandemic. Emerg Infect Dis. 2006;12:881-6.
9. Younan M, Poh MK, Elassal E, Davis T, Rivailler P, Balish AL, et al Microevolution of highly pathogenic avian influenza a(H5N1) viruses isolated from humans, Egypt, 2007-2011. Emerg Infect Dis. 2013;19:43-50.

10. El-Shesheny R, Kandeil A, Bagato O, Maatouq AM, Moatasim Y, Rubrum A, et al. Molecular characterization of avian influenza H5N1 virus in Egypt and the emergence of a novel endemic subclade. J Gen Virol. 2014;95(Pt_7):1444-63.

11. Baigent SJ, McCauley JW. Influenza type a in humans, mammals and birds: determinants of virus virulence, host-range and interspecies transmission. BioEssays. 2003;25:657-71.

12. Abdelwhab EM, Hafez HM. An overview of the epidemic of highly pathogenic H5N1 avian influenza virus in Egypt: epidemiology and control challenges. Epidemiol Infect. 2011;139:647-57.

13. Alkhamis MA, Hijmans RJ, Al-Enezi A, Martínez-López B, Perez AM. The use of spatial and spatio-temporal modeling for surveillance of $\mathrm{H} 5 \mathrm{~N} 1$ highly pathogenic avian influenza in poultry in the Middle East. Avian Diseases. 2016;60:146-55

14. Kayali G, Webby RJ, Ducatez MF, El Shesheny RA, Kandeil AM, Govorkova EA et al. The epidemiological and molecular aspects of influenza H5N1 viruses at the human-animal interface in Egypt. PLoS One. 2011;6:e17730.

15. Kim J-K, Negovetich NJ, Forrest HL, Webster RG. Ducks: the "Trojan horses" of H5N1 influenza. Influenza Other Respir Viruses. 2009:3:121-8.

16. Magee D, Beard R, Suchard MA, Lemey P, Scotch M. Combining phylogeography and spatial epidemiology to uncover predictors of $\mathrm{H} 5 \mathrm{~N} 1$ influenza a virus diffusion. Arch Virol. 2015;160:215-24.

17. World Health Organization. Cumulative number of confirmed human cases for avian influenza A(H5N1) reported to WHO, 2003-2016: WHO; 2016. http://www.who.int/influenza/human_animal_interface/2016_11_21_ tableH5N1corrected.pdf?ua=1. Accessed 22 Dec 2016

18. Refaey S, Azziz-Baumgartner E, Amin MM, Fahim M, Roguski K, Elaziz HAEA, et al. Increased number of human cases of influenza virus a(H5N1) infection Egypt, 2014-15. Emerg Infect Dis. 2015;21:2171-3.

19. Kandeel A, Manoncourt S, el Kareem EA, Ahmed A-NM, El-Refaie S, Essmat $\mathrm{H}$, et al. Zoonotic transmission of avian influenza virus (H5N1), Egypt, 20062009. Emerg Infect Dis. 2010;16:1101-7.

20. Taha FA. Poultry sector in Middle-income countries and its feed requirements: the case of Egypt. Agriculture and Trade Report. Washington, D.C.: United States Department of Agriculture, Economic Research Service; 2003.

21. Gomaa MR, Kayed AS, Elabd MA, Zeid DA, Zaki SA, El Rifay AS, et al. Avian influenza a(H5N1) and a(H9N2) seroprevalence and risk factors for infection among Egyptians: a prospective, controlled seroepidemiological study. J Infect Dis. 2015;211:1399-407.

22. Parrish CR, Holmes EC, Morens DM, Park E-C, Burke DS, Calisher $\mathrm{CH}$, et al. Cross-species virus transmission and the emergence of new epidemic diseases. Microbiol Mol Biol Rev. 2008;72:457-70.

23. Woolhouse MEJ, Haydon DT, Antia R. Emerging pathogens: the epidemiology and evolution of species jumps. Trends Ecol Evol. 2005;20:238-44.

24. Salomon R, Webster RG. The influenza virus enigma. Cell. 2009;136:402-10.

25. Chen L-M, Blixt O, Stevens J, Lipatov AS, Davis CT, Collins BE, et al. In vitro evolution of H5N1 avian influenza virus toward human-type receptor specificity. Virology. 2012:422:105-13.

26. Gabriel G, Dauber B, Wolff T, Planz O, Klenk H-D, Stech J. The vira polymerase mediates adaptation of an avian influenza virus to a mammalian host. Proc Natl Acad Sci U S A. 2005:102:18590-5.

27. Li Z, Chen H, Jiao P, Deng G, Tian G, Li Y, et al. Molecular basis of replication of duck H5N1 influenza viruses in a mammalian mouse model. J Virol. 2005; 79:12058-64.

28. Subbarao EK, London W. Murphy BR. A single amino acid in the PB2 gene of influenza a virus is a determinant of host range. J Virol. 1993;67:1761-4.

29. Hatta M, Gao P, Halfmann P, Kawaoka Y. Molecular basis for high virulence of Hong Kong H5N1 influenza a viruses. Science. 2001;293:1840-2.

30. Yoon S-W, Kayali G, Ali MA, Webster RG, Webby RJ, Ducatez MF. A single amino acid at the hemagglutinin cleavage site contributes to the pathogenicity but not the transmission of Egyptian highly pathogenic $\mathrm{H} 5 \mathrm{~N}$ influenza virus in chickens. J Virol. 2013:87:4786-8.

31. Herfst $S$, Schrauwen EJA, Linster M, Chutinimitkul S, de Wit E, Munster VJ, et al. Airborne transmission of influenza a/H5N1 virus between ferrets. Science. 2012;336:1534-41.

32. Siddique N, Naeem K, Abbas MA, Ahmed Z, Malik SA. Sequence and phylogenetic analysis of highly pathogenic avian influenza H5N1 viruses isolated during 2006-2008 outbreaks in Pakistan reveals genetic diversity. Virol J. 2012;9:300 
33. Bloom JD, Gong LI, Baltimore D. Permissive secondary mutations enable the evolution of influenza oseltamivir resistance. Science. 2010;328:1272-5.

34. Arafa A-S, Yamada S, Imai M, Watanabe T, Yamayoshi S, Iwatsuki-Horimoto $\mathrm{K}$, et al. Risk assessment of recent Egyptian H5N1 influenza viruses. Sci Rep. 2016;6:38388.

35. Watanabe Y, Arai Y, Daidoji T, Kawashita N, Ibrahim MS, El-Gendy EE-DM, et al. Characterization of $\mathrm{H} 5 \mathrm{~N} 1$ influenza virus variants with hemagglutinin mutations isolated from patients. MBio. 2015;6:e00081-15.

36. Imai M, Watanabe T, Hatta M, Das SC, Ozawa M, Shinya K, et al. Experimental adaptation of an influenza $\mathrm{H} 5 \mathrm{HA}$ confers respiratory droplet transmission to a reassortant H5 HA/H1N1 virus in ferrets. Nature. 2012; https://doi.org/10.1038/nature10831.

37. Benson DA, Karsch-Mizrachi I, Lipman DJ, Ostell J, Wheeler DL. GenBank. Nucleic Acids Res. 2007;36(Database):D25-30.

38. Wheeler DC. A comparison of spatial clustering and cluster detection techniques for childhood leukemia incidence in Ohio, 1996 - 2003. Int J Health Geogr. 2007;6:13.

39. Rellstab C, Gugerli F, Eckert AJ, Hancock AM, Holderegger R. A practical guide to environmental association analysis in landscape genomics. Mol Ecol. 2015;24:4348-70.

40. Bao Y, Bolotov P, Dernovoy D, Kiryutin B, Zaslavsky L, Tatusova T, et al. The influenza virus resource at the National Center for biotechnology information. J Virol. 2008;82:596-601.

41. Kans J. Entrez direct: E-utilities on the UNIX command line. 2016. http:// www.ncbi.nlm.nih.gov/books/NBK179288. Accessed 16 Dec 2016.

42. Yen $\mathrm{H}$-L, Aldridge JR, Boon ACM, Ilyushina NA, Salomon R, Hulse-Post DJ, et al. Changes in $\mathrm{H} 5 \mathrm{~N} 1$ influenza virus hemagglutinin receptor binding domain affect systemic spread. Proc Natl Acad Sci. 2009;106:286-91.

43. Conenello GM, Tisoncik JR, Rosenzweig E, Varga ZT, Palese P, Katze MG. A single N665 mutation in the PB1-F2 protein of influenza a virus increases virulence by inhibiting the early interferon response in vivo. J Virol. 2011;85:652-62.

44. Conenello GM, Zamarin D, Perrone LA, Tumpey T, Palese P. A single mutation in the PB1-F2 of H5N1 (HK/97) and 1918 influenza a viruses contributes to increased virulence. PLoS Pathog. 2007;3:e141.

45. Schmolke M, Manicassamy B, Pena L, Sutton T, Hai R, Varga ZT, et al. Differential contribution of PB1-F2 to the virulence of highly pathogenic H5N1 influenza a virus in mammalian and avian species. PLoS Pathog. 2011;7:e1002186.

46. Centers for Disease Control and Prevention, World Health Organization. Influenza H5N1 Genetic Changes Inventory. 2012. https://www.cdc.gov/flu/ pdf/avianflu/h5n1-inventory.pdf. Accessed 7 Jan 2017.

47. Malcolm BL. The spread process of epidemic influenza in the continental United States, 1968-2008. Spat Spatio-Temporal Epidemiol. 2014;8:35-45.

48. Rezaeian M, Dunn G, St Leger S, Appleby L. Geographical epidemiology, spatial analysis and geographical information systems: a multidisciplinary glossary. J Epidemiol Community Health. 2007;61:98-102

49. Getis A, Ord JK. The analysis of spatial association by use of distance statistics. Geogr Anal. 1992;24:189-206.

50. Barro AS, Kracalik IT, Malania L, Tsertsvadze N, Manvelyan J, Imnadze P, et al. Identifying hotspots of human anthrax transmission using three local clustering techniques. Appl Geogr. 2015;60:29-36.

51. Moran PAP. Notes on continuous stochastic phenomena. Biometrika. 1950; 37:17-23.

52. Stopka TJ, Krawczyk C, Gradziel P, Geraghty EM. Use of spatial epidemiology and hot spot analysis to target women eligible for prenatal women, infants, and children services. Am J Public Health. 2014;104:S183-9.

53. Zhang Y, Shen Z, Ma C, Jiang C, Feng C, Shankar N, et al. Cluster of human infections with avian influenza a (H7N9) cases: a temporal and spatial analysis. Int J Environ Res Public Health. 2015;12:816-28.

54. Benjamini $Y$, Hochberg Y. Controlling the false discovery rate - a practical and powerful approach. J R Stat Soc Ser B-Methodol. 1995;57:289-300.

55. Caldas de Castro M, Singer BH. Controlling the false discovery rate: a new application to account for multiple and dependent tests in local statistics of spatial association. Geogr Anal. 2006:38:180-208.

56. Linard C, Tatem AJ. Large-scale spatial population databases in infectious disease research. Int J Health Geogr. 2012;11:7.

57. Linard C, Gilbert M, Snow RW, Noor AM, Tatem AJ. Population distribution, settlement patterns and accessibility across Africa in 2010 PLoS One. 2012;7:e31743.

58. Scotch M, Mei C, Makonnen YJ, Pinto J, Ali A, Vegso S, et al. Phylogeography of influenza a H5N1 clade 2.2.1.1 in Egypt. BMC Genomics. 2013;14:871.
59. Su Y, Yang H-Y, Zhang B-J, Jia H-L, Tien P. Analysis of a point mutation in H5N1 avian influenza virus hemagglutinin in relation to virus entry into live mammalian cells. Arch Virol. 2008;153:2253-61.

60. Li J, Ishaq M, Prudence M, Xi X, Hu T, Liu Q, et al. Single mutation at the amino acid position 627 of PB2 that leads to increased virulence of an H5N1 avian influenza virus during adaptation in mice can be compensated by multiple mutations at other sites of PB2. Virus Res. 2009;144:123-9.

61. Clegg CH, Roque R, Van Hoeven N, Perrone L, Baldwin SL, Rininger JA, et al. Adjuvant solution for pandemic influenza vaccine production. Proc Natl Acad Sci. 2012;109:17585-90.

62. El-Zoghby EF, Arafa A-S, Kilany WH, Aly MM, Abdelwhab EM, Hafez HM. Isolation of avian influenza H5N1 virus from vaccinated commercial layer flock in Egypt. Virol J. 2012;9:294.

63. Hafez MH, Arafa A, Abdelwhab EM, Selim A, Khoulosy SG, Hassan MK, et al. Avian influenza H5N1 virus infections in vaccinated commercial and backyard poultry in Egypt. Poult Sci. 2010;89:1609-13.

64. Fasina FO, Ifende VI, Ajibade AA. Avian influenza a (H5N1) in humans: lessons from Egypt. Euro Surveill. 2010;15:19473.

65. Samaha H, Ibrahim MS, Ayoub M, Shaaban SI. Seroepidemiology of avian influenza viruses $\mathrm{H} 5$ and $\mathrm{H} 9$ in Beheira governorate. Alex J Vet Sci. 2015:44:86

66. Bruun B, El Din SB. Common birds of Egypt: with a checklist of the birds of Egypt. Rev. ed. Cairo: American Univ. in Cairo Press; 1990.

67. Li XH, Tian HD, Heiner M, Li DM. Global occurrence and spread of highly pathogenic avian influenza virus of the subtype H5N1. Avian Dis. 2011;55:21-8

68. Tian H, Zhou S, Dong L, Van Boeckel TP, Cui Y, Wu Y, et al. Avian influenza H5N1 viral and bird migration networks in Asia. Proc Natl Acad Sci. 2015; 112:172-7.

69. Soliman A, Saad M, Elassal E, Amir E, Plathonoff C, Bahgat V, et al. Surveillance of avian influenza viruses in migratory birds in Egypt, 2003-09. J Wildl Dis. 2012;48:669-75.

70. Scotch M, Sarkar IN, Mei C, Leaman R, Cheung K-H, Ortiz P, et al. Enhancing phylogeography by improving geographical information from GenBank. J Biomed Inform. 2011:44:S44-7.

71. Jacquez GM. A research agenda: does geocoding positional error matter in health GIS studies? Spat Spatio-Temporal Epidemiol. 2012;3:7-16.

72. Janies D, Hill AW, Guralnick R, Habib F, Waltari E, Wheeler WC. Genomic analysis and geographic visualization of the spread of avian influenza (H5N1). Syst Biol. 2007:56:321-9.

73. Li R, Jiang Z, Xu B. Global spatiotemporal and genetic footprint of the H5N1 avian influenza virus. Int J Health Geogr. 2014;13:14.

74. Liang $L, X u B$, Chen $Y$, Liu Y, Cao W, Fang $L$, et al. Combining spatialtemporal and phylogenetic analysis approaches for improved understanding on global H5N1 transmission. PLoS One. 2010;5:e13575.

75. Wallace RG, Fitch WM. Influenza a H5N1 immigration is filtered out at some international borders. PLoS One. 2008;3:e1697.

76. Casadevall A, Shenk T. The H5N1 moratorium controversy and debate. MBio. 2012:3:e00379-12.

77. Yang Z-Y, Wei C-J, Kong W-P, Wu L, Xu L, Smith DF, et al. Immunization by avian $\mathrm{H} 5$ influenza hemagglutinin mutants with altered receptor binding specificity. Science. 2007;317:825-8.

78. Kongchanagul A, Suptawiwat O, Kanrai P, Uiprasertkul M, Puthavathana P, Auewarakul P. Positive selection at the receptor-binding site of haemagglutinin $\mathrm{H} 5$ in viral sequences derived from human tissues. J Gen Virol. 2008;89:1805-10

79. Naughtin M, Dyason JC, Mardy S, Sorn S, von Itzstein M, Buchy P. Neuraminidase inhibitor sensitivity and receptor-binding specificity of Cambodian clade 1 highly pathogenic H5N1 influenza virus. Antimicrob Agents Chemother. 2011;55:2004-10.

80. Yamada S, Suzuki Y, Suzuki T, Le MQ, Nidom CA, Sakai-Tagawa Y, et al. Haemagglutinin mutations responsible for the binding of $\mathrm{H} 5 \mathrm{~N} 1$ influenza a viruses to human-type receptors. Nature. 2006;444:378-82.

81. Wang W, Lu B, Zhou H, Suguitan AL, Cheng X, Subbarao K, et al. Glycosylation at $158 \mathrm{~N}$ of the hemagglutinin protein and receptor binding specificity synergistically affect the antigenicity and immunogenicity of a live attenuated H5N1 a/Vietnam/1203/2004 vaccine virus in ferrets. J Virol. 2010;84:6570-7.

82. Gao Y, Zhang Y, Shinya K, Deng G, Jiang Y, Li Z, et al. Identification of amino acids in HA and PB2 critical for the transmission of H5N1 avian influenza viruses in a mammalian host. PLoS Pathog. 2009;5:e1000709. 
83. Chutinimitkul S, van Riel D, Munster VJ, van den Brand JMA, Rimmelzwaan GF, Kuiken T, et al. In vitro assessment of attachment pattern and replication efficiency of $\mathrm{H} 5 \mathrm{~N} 1$ influenza a viruses with altered receptor specificity. J Virol. 2010;84:6825-33.

84. Watanabe Y, Ibrahim MS, Ellakany HF, Kawashita N, Mizuike R, Hiramatsu H, et al. Acquisition of human-type receptor binding specificity by new $\mathrm{H} 5 \mathrm{~N} 1$ influenza virus sublineages during their emergence in birds in Egypt. PLoS Pathog. 2011;7:e1002068.

85. Shinya K, Makino A, Hatta M, Watanabe S, Kim JH, Kawaoka Y. A mutation in $\mathrm{H} 5$ haemagglutinin that conferred human receptor recognition is not maintained stably during duck passage. J Gen Virol. 2010;91:1461-3.

86. Gambaryan A, Tuzikov A, Pazynina G, Bovin N, Balish A, Klimov A. Evolution of the receptor binding phenotype of influenza a (H5) viruses. Virology. 2006;344:432-8.

87. Auewarakul P, Suptawiwat O, Kongchanagul A, Sangma C, Suzuki Y, Ungchusak K, et al. An avian influenza H5N1 virus that binds to a humantype receptor. J Virol. 2007:81:9950-5.

88. Fan S, Deng G, Song J, Tian G, Suo Y, Jiang Y, et al. Two amino acid residues in the matrix protein $\mathrm{M} 1$ contribute to the virulence difference of H5N1 avian influenza viruses in mice. Virology. 2009;384:28-32.

89. Lan Y, Zhang Y, Dong L, Wang D, Huang W, Xin L, et al. A comprehensive surveillance of adamantane resistance among human influenza a virus isolated from mainland China between 1956 and 2009. Antivir Ther. 2010; 15:853-60.

90. Ilyushina NA, Govorkova EA, Webster RG. Detection of amantadine-resistant variants among avian influenza viruses isolated in North America and Asia. Virology. 2005;341:102-6.

91. Abed Y, Goyette N, Boivin G. Generation and characterization of recombinant influenza a (H1N1) viruses harboring amantadine resistance mutations. Antimicrob Agents Chemother. 2005;49:556-9.

92. Cheung C-L, Rayner JM, Smith GJD, Wang P, Naipospos TSP, Zhang J, et al. Distribution of amantadine-resistant H5N1 avian influenza variants in Asia. J Infect Dis. 2006;193:1626-9.

93. Buranathai C, Amonsin A, Chaisigh A, Theamboonlers A, Pariyothorn N, Poovorawan Y. Surveillance activities and molecular analysis of H5N1 highly pathogenic avian influenza viruses from Thailand, 2004-2005. Avian Dis. 2007:51:194-200.

94. He G, Qiao J, Dong C, He C, Zhao L, Tian Y. Amantadine-resistance among H5N1 avian influenza viruses isolated in northern China. Antivir Res. 2008;77:72-6.

95. Puthavathana $P$, Auewarakul P, Charoenying PC, Sangsiriwut K, Pooruk $P$, Boonnak $K$, et al. Molecular characterization of the complete genome of human influenza H5N1 virus isolates from Thailand. J Gen Virol. 2005;86:423-33

96. Cinatl J, Michaelis M, Doerr HW. The threat of avian influenza a (H5N1). Part III: antiviral therapy. Med Microbiol Immunol (Berl). 2007;196:203-12.

97. Bean WJ, Threlkeld SC, Webster RG. Biologic potential of amantadineresistant influenza a virus in an avian model. J Infect Dis. 1989;159:1050-6.

98. Matsuoka Y, Swayne DE, Thomas C, Rameix-Welti M-A, Naffakh N, Warnes C, et al. Neuraminidase stalk length and additional glycosylation of the hemagglutinin influence the virulence of influenza H5N1 viruses for mice. J Virol. 2009;83:4704-8.

99. Zhou H, Yu Z, Hu Y, Tu J, Zou W, Peng Y, et al. The special neuraminidase stalk-motif responsible for increased virulence and pathogenesis of H5N1 influenza a virus. PLoS One. 2009;4:e6277.

100. Hurt AC, Selleck P, Komadina N, Shaw R, Brown L, Barr IG. Susceptibility of highly pathogenic a(H5N1) avian influenza viruses to the neuraminidase inhibitors and adamantanes. Antivir Res. 2007;73:228-31.

101. Le MTQ, Wertheim HFL, Nguyen HD, Taylor W, Hoang PVM, Vuong CD, et al. Influenza a H5N1 clade 2.3.4 virus with a different antiviral susceptibility profile replaced clade 1 virus in humans in northern Vietnam. PLoS One. 2008:3:e3339.

102. Ilyushina NA, Seiler JP, Rehg JE, Webster RG, Govorkova EA. Effect of neuraminidase inhibitor-resistant mutations on pathogenicity of clade 2.2 a/Turkey/15/06 (H5N1) influenza virus in ferrets. PLoS Pathog. 2010;6: e1000933.

103. Hurt AC, Holien JK, Parker M, Kelso A, Barr IG. Zanamivir-resistant influenza viruses with a novel neuraminidase mutation. J Virol. 2009;83:10366-73.

104. Boltz DA, Douangngeun B, Phommachanh P, Sinthasak S, Mondry R, Obert $\mathrm{C}$, et al. Emergence of $\mathrm{H} 5 \mathrm{~N} 1$ avian influenza viruses with reduced sensitivity to neuraminidase inhibitors and novel reassortants in Lao People's Democratic Republic. J Gen Virol. 2010;91:949-59.
105. Wibawa H, Henning J, Wong F, Selleck P, Junaidi A, Bingham J, et al. A molecular and antigenic survey of H5N1 highly pathogenic avian influenza virus isolates from smallholder duck farms in Central Java, Indonesia during 2007-2008. Virol J. 2011;8:425

106. Pizzorno A, Bouhy X, Abed Y, Boivin G. Generation and characterization of recombinant pandemic influenza a(H1N1) viruses resistant to neuraminidase inhibitors. J Infect Dis. 2011;203:25-31.

107. Nguyen JT, Hoopes JD, Le MH, Smee DF, Patick AK, Faix DJ, et al. Triple combination of amantadine, ribavirin, and oseltamivir is highly active and synergistic against drug resistant influenza virus strains in vitro. PLoS One. 2010;5:e9332.

108. Hill AW, Guralnick RP, Wilson MJC, Habib F, Janies D. Evolution of drug resistance in multiple distinct lineages of H5N1 avian influenza. Infect Genet Evol. 2009;9:169-78.

109. Le QM, Kiso M, Someya K, Sakai YT, Nguyen TH, Nguyen KHL, et al. Isolation of drug-resistant H5N1 virus. Nature. 2005;437:1108.

110. Govorkova EA, llyushina NA, Boltz DA, Douglas A, Yilmaz N, Webster RG. Efficacy of oseltamivir therapy in ferrets inoculated with different clades of H5N1 influenza virus. Antimicrob Agents Chemother. 2007;51:1414-24.

111. de Jong MD, Cam BV, Qui PT, Hien VM, Thanh TT, Hue NB, et al. Fatal avian influenza a $(\mathrm{H} 5 \mathrm{~N} 1)$ in a child presenting with diarrhea followed by coma. $\mathrm{N}$ Engl J Med. 2005;352:686-91.

112. Gubareva LV, Kaiser L, Matrosovich MN, Soo-Hoo Y, Hayden FG. Selection of influenza virus mutants in experimentally infected volunteers treated with oseltamivir. J Infect Dis. 2001;183:523-31.

113. Earhart KC, Elsayed NM, Saad MD, Gubareva LV, Nayel A, Deyde VM, et al. Oseltamivir resistance mutation N294S in human influenza a(H5N1) virus in Egypt. J Infect Public Health. 2009;2:74-80.

114. Yen H-L, llyushina NA, Salomon R, Hoffmann E, Webster RG, Govorkova EA. Neuraminidase inhibitor-resistant recombinant a/Vietnam/1203/04 (H5N1) influenza viruses retain their replication efficiency and pathogenicity in vitro and in vivo. J Virol. 2007;81:12418-26.

115. Kiso M, Ozawa M, Le M t Q, Imai H, Takahashi K, Kakugawa S, et al. Effect of an asparagine-to-serine mutation at position 294 in neuraminidase on the pathogenicity of highly pathogenic H5N1 influenza a virus. J Virol. 2011;85: 4667-72.

116. Jiao $P$, Tian G, Li Y, Deng G, Jiang Y, Liu C, et al. A single-amino-acid substitution in the NS1 protein changes the pathogenicity of $\mathrm{H} 5 \mathrm{~N} 1$ avian influenza viruses in mice. J Virol. 2008:82:1146-54.

117. Long J-X, Peng D-X, Liu Y-L, Wu Y-T, Liu X-F. Virulence of H5N1 avian influenza virus enhanced by a 15 -nucleotide deletion in the viral nonstructural gene. Virus Genes. 2008;36:471-8.

118. Heui Seo S, Hoffmann E, Webster RG. Lethal H5N1 influenza viruses escape host anti-viral cytokine responses. Nat Med. 2002;8:950-4.

119. Kuo R-L, Krug RM. Influenza a virus polymerase is an integral component of the CPSF30-NS1A protein complex in infected cells. J Virol. 2009;83:1611-6.

120. Spesock A, Malur M, Hossain MJ, Chen L-M, Njaa BL, Davis CT, et al. The virulence of $1997 \mathrm{H} 5 \mathrm{~N} 1$ influenza viruses in the mouse model is increased by correcting a defect in their NS1 proteins. J Virol. 2011;85:7048-58.

121. Imai H, Shinya K, Takano R, Kiso M, Muramoto Y, Sakabe S, et al. The HA and NS genes of human $\mathrm{H} 5 \mathrm{~N} 1$ influenza a virus contribute to high virulence in ferrets. PLoS Pathog. 2010;6:e1001106

122. Shinya K, Hamm S, Hatta M, Ito H, Ito T, Kawaoka Y. PB2 amino acid at position 627 affects replicative efficiency, but not cell tropism, of Hong Kong H5N1 influenza a viruses in mice. Virology. 2004;320:258-66.

123. Chen H, Bright RA, Subbarao K, Smith C, Cox NJ, Katz JM, et al. Polygenic virulence factors involved in pathogenesis of 1997 Hong Kong H5N1 influenza viruses in mice. Virus Res. 2007;128:159-63.

124. Kim JH, Hatta M, Watanabe S, Neumann G, Watanabe T, Kawaoka Y. Role of host-specific amino acids in the pathogenicity of avian $\mathrm{H} 5 \mathrm{~N} 1$ influenza viruses in mice. J Gen Virol. 2010;91:1284-9.

125. Mase M, Tanimura N, Imada T, Okamatsu M, Tsukamoto K, Yamaguchi S. Recent H5N1 avian influenza a virus increases rapidly in virulence to mice after a single passage in mice. J Gen Virol. 2006;87:3655-9.

126. Fornek JL, Gillim-Ross L, Santos C, Carter V, Ward JM, Cheng LI, et al. A single-amino-acid substitution in a polymerase protein of an H5N1 influenza virus is associated with systemic infection and impaired T-cell activation in mice. J Virol. 2009;83:11102-15.

127. Le QM, Sakai-Tagawa Y, Ozawa M, Ito M, Kawaoka Y. Selection of H5N1 influenza virus PB2 during replication in humans. J Virol. 2009;83:5278-81.

128. Manzoor R, Sakoda Y, Nomura N, Tsuda Y, Ozaki H, Okamatsu M, et al. PB2 protein of a highly pathogenic avian influenza virus strain a/chicken/ 
Yamaguchi/7/2004 (H5N1) determines its replication potential in pigs. J Virol. 2009;83:1572-8.

129. Bogs J, Kalthoff D, Veits J, Pavlova S, Schwemmle M, Manz B, et al. Reversion of PB2-627E to -627K during replication of an $\mathrm{H} 5 \mathrm{~N} 1$ clade 2.2 virus in mammalian hosts depends on the origin of the nucleoprotein. J Virol. 2011; 85:10691-8.

130. Hatta M, Hatta Y, Kim JH, Watanabe S, Shinya K, Nguyen T, et al. Growth of H5N1 influenza a viruses in the upper respiratory tracts of mice. PLoS Pathog. 2007;3:e133.

131. Bortz E, Westera L, Maamary J, Steel J, Albrecht RA, Manicassamy B, et al. Host-and strain-specific regulation of influenza virus polymerase activity by interacting cellular proteins. MBio. 2011;2:e00151-11.

132. Steel J, Lowen AC, Mubareka S, Palese P. Transmission of influenza virus in a mammalian host is increased by PB2 amino acids 627K or 627E/701N. PLoS Pathog. 2009;5:e1000252

Ready to submit your research? Choose BMC and benefit from:

- fast, convenient online submission

- thorough peer review by experienced researchers in your field

- rapid publication on acceptance

- support for research data, including large and complex data types

- gold Open Access which fosters wider collaboration and increased citations

- maximum visibility for your research: over $100 \mathrm{M}$ website views per year 